\title{
Senescence of Cultured Porcine Coronary Arterial Endothelial Cells Is Associated with Accelerated Oxidative Stress and Activation of NFkB
}

\author{
Mary Y.K. Lee Yu Wang Paul M. Vanhoutte \\ Department of Pharmacology and Pharmacy, Li Ka Shing Faculty of Medicine, University of Hong Kong, \\ Hong Kong, SAR, China
}

\section{Key Words}

Endothelial cells $\cdot$ eNOS $\cdot N F \kappa B \cdot$ Oxidative stress • p53 •

Senescence

\begin{abstract}
Aims: Endothelial dysfunction occurs following multiple passaging in vitro, but the molecular mechanisms involved remain unidentified. The present study defined the genomic changes related to dysfunction in cultured senescent endothelial cells. Methods and Results: Senescent cells were produced by multiple passaging of porcine coronary arterial endothelial cells for up to 4 weeks. Genomic and proteomic studies on cultured cells at the first passage (P1) and the fourth passage (P4) were performed. Senescence and decreased NO production were observed in cells and several signaling pathways - such as IFN/STAT, IGF, TGF- $\beta$, cytoskeleton rearrangement and lipid metabolism - were altered at P4, as judged from the microarray analysis. The basal and stimulated (by TNF- $\alpha$ ) levels of NFKB were augmented in senescent cells in electrophoretic mobility shift assays in association with increased oxidative stress, increased $\mathrm{p} 53$ protein stability, and activated apoptotic pathways. The increased oxidative stress was alleviated by treatment with the superoxide dismutase mimetic MnTMPyP. Conclusions: After multiple passaging in vitro, porcine coronary endothelial cells
\end{abstract}

exhibited dysfunction and senescence associated with reduced proliferative capacity, increased oxidative stress, and activation of the NFKB and p53 signaling pathways.

Copyright ๑ 2009 S. Karger AG, Basel

\section{Introduction}

Endothelial cells undergo senescence both in vivo and in vitro [1-8]. Since endothelial cells are a critical component of the vasculature, their senescence can have a significant impact on vascular integrity and function and on the progression of vascular disease $[4,5]$.

Multiple in vitro passaging of cell cultures derived from native endothelial cells may represent a relevant experimental model for the study of pathological endothelial regeneration and aging in vivo $[3,4,7,9]$ if the multiple passaging were to induce identical genomic and proteomic changes as observed in regenerated cells. Different cell types tend to show distinct gene expression patterns despite of the common initiator, replicative senescence. Study of the alteration in gene expression in human umbilical vein endothelial cells shows differential changes after multiple passaging under high- and low-serum conditions [10]. The present experiments were designed to investigate the gene expression changes in native cul-

\section{KARGER}

Fax +4161306 1234 E-Mail karger@karger.ch www.karger.com
(C) 2009 S. Karger AG, Basel

$1018-1172 / 10 / 0474-0287 \$ 26.00 / 0$

Accessible online at:

www.karger.com/jvr
Prof. Paul M. Vanhoutte

Department of Pharmacology and Pharmacy

Li Ka Shing Faculty of Medicine, University of Hong Kong

L2-48, Laboratory Block, 21 Sassoon Road, Pokfulam, Hong Kong, SAR (China)

Tel. +852 2819 9250, Fax +852 2817 0859, E-Mail vanhoutt@ hkucc.hku.hk 
tured coronary arterial endothelial cells after multiple passaging, and the molecular mechanisms leading to their dysfunction and senescence. The present results demonstrate that the senescence induced by replication until the fourth passage in vitro leads to a number of deranged signaling mechanisms, including increased oxidative stress and activation of the p53 and NFкB pathways. Multiple passaging in vitro appears to be a suitable model for the study of endothelial senescence, but not of regeneration.

\section{Experimental Procedures}

\section{Isolation and Culture of Coronary Endothelial Cells}

Hearts from female farm pigs (aged 3-4 months; $25-30 \mathrm{~kg}$ ) were collected and transferred into cold Earle's balanced salt solution supplemented with 5\% FBS. To prepare cultures for passage 1 (week 1; P1) and 4 (week 4; P4), endothelial cells were harvested from the left circumflex, left anterior descending artery and right coronary arteries [1]. The cells were cultured at $37^{\circ} \mathrm{C}$ in humidified $5 \% \mathrm{CO}_{2} 95 \%$ air. The medium was changed every $48 \mathrm{~h}$ for 1 week until the cells reached confluence (passage 0 ). Cells were detached with trypsin-EDTA (Gibco-BRL, Grand Island, N.Y., USA) and further passaged at a ratio of 1:3 at regular intervals (once per week) for 4 weeks until senescence was reached. To investigate the involvement of oxidative stress in endothelial senescence, cultured cells at passage 1 were treated with hydrogen peroxide $\left(\mathrm{H}_{2} \mathrm{O}_{2} ; 100 \mu \mathrm{M}\right)[11]$ in the presence or absence of the SOD mimetic MnTMPyP $\left(10^{-6} \mathrm{M}\right)$ [12] for $1 \mathrm{~h}$. After incubation in normal culture medium for $24 \mathrm{~h}$, the cells were harvested for further evaluation.

\section{Characterization of Senescent Cells}

Crystal Violet Staining and Cell Proliferation

Measurement [13]

Cell nuclei were stained with crystal violet dye and the excess dye washed out before optical density measurements at $570 \mathrm{~nm}$. For proliferation measurement, cells were seeded at a density of $1 \times 10^{3}$ in 96 -well plates. The culture medium was changed every 2 days. Briefly, at each time point, the media were removed and cells washed with PBS, fixed with $100 \mu \mathrm{l}$ of $100 \%$ methanol followed by staining with $0.2 \%$ crystal violet dye solution in $20 \%$ methanol for $15 \mathrm{~min}$. Excess dye was removed by gentle washing with double-distilled water followed by air drying. Stained cells were solubilized with $1 \%$ SDS and quantified using $\mu$ Quant MQX200 microplate reader (Biotek Instruments, Winooski, Vt., USA).

\section{Population Doubling [14]}

Population doubling $=\left(\log _{10} \mathrm{~F}-\log _{10} \mathrm{I}\right) / 0.301$, where $\mathrm{F}$ is the number of cells at the end of one passage, and $I$ is the number of cells that were seeded at the beginning of the passage. Similarly, endothelial cell growth was estimated from P1 until P4 by calculating the number of cells on 3 consecutive days after each passage.
Telomerase Activity [15]

Cell lysates were prepared from $80 \%$ confluent cultures at P1 and $\mathrm{P} 4$ according to the manufacturer's instructions. Briefly, cultured cells were harvested by trypsinization (Gibco-BRL) and extracted in Chaps XL lysis buffer at $4^{\circ} \mathrm{C}$. Two microliters of cell lysates, equivalent to $1 \mu \mathrm{g}$ protein (approximately $2 \times 10^{4}$ cells), were used for the telomerase activity assay (Trapeze ${ }^{\circledR}$ XL telomerase detection kit; Chemicon International, Temecula, Calif., USA). Cancer cell extract equivalent to 1,000 cells was used as the positive control in the experiment.

Histochemical Staining for Senescence-Associated

Galactosidase- $\beta 1$

Cells were seeded in a culture plate overnight, washed 3 times with PBS and fixed with $2 \%$ formaldehyde $/ 0.2 \%$ glutaraldehyde in PBS for $10 \mathrm{~min}$. After extensive washing, the cells were incubated with freshly prepared $\beta$-galactosidase (SA- $\beta$-Gal) [1] substrate staining solution $(150 \mathrm{mM} \mathrm{NaCl}, 2 \mathrm{mM} \mathrm{MgCl}, 5 \mathrm{~mm}$ potassium ferricyanide, $5 \mathrm{mM}$ potassium ferrocyanide, $40 \mathrm{mM}$ citric acid, $12 \mathrm{~mm}$ sodium phosphate, $1 \mathrm{mg} / \mathrm{ml}$ 5-bromo-4-chloro-3-indolyl- $\beta$-D-galactoside) at $\mathrm{pH} 6$, and incubated at $37^{\circ} \mathrm{C}$ for $16 \mathrm{~h}$. The preparations were dehydrated with graded ethanol solutions (80, 90 and $100 \%$; 3 min). The stained (light blue) cells were detected by conventional microscopy.

\section{Global Gene Expression Analysis in Senescent Cells RNA}

Extraction

Cultures of isolated endothelial cells at P1 and P4, derived from at least 3 pigs, were used for isolation of the RNA for subsequent microarray analysis using a RNeasy Mini kit (Qiagen; Valencia, Calif., USA) as described previously. The total amount of RNA was quantified by measuring the optical density at $260 \mathrm{~nm}$. The ratio of absorption (260/280) of all samples was between 1.7 and 2.1. The integrity of RNA samples was assessed using a Bioanalyzer (Agilent Technology; Santa Clara, Calif., USA).

Microarray Analysis [1]

High quality RNA ( $1 \mu \mathrm{g}$; from cells at P1 and P4) was used for experiments with the GeneChip ${ }^{\circledR}$ Porcine Genome Array (Affymetrix; Santa Clara, Calif., USA), according to the manufacturer's instructions. The intensity of each feature of the array was captured with Affymetrix GeneChip Expression Analysis Software (GeneChip Operating System). The detailed description of each probe set ID of the GeneChip porcine genome array can be found on the Affymetrix website (www.affymetrix.com/index. affx). Certain changed genes were subjected to computational simulation of biological interactions [pathway analysis; PathwayArchitect ${ }^{\mathrm{TM}}$; Stratagene v.3 (2007)].

\section{Real-Time Quantitative PCR [1]}

Five hundred nanograms of total RNA were used for reverse transcription. One microliter of the total reverse transcription product was added to PCR reaction mixture $(20 \mu \mathrm{l})$ containing 10 $\mu 12 \times$ SYBR $^{\circledR}$ Green PCR master mix (Applied Biosystems, UK) and the primers (sense and anti-sense; $1 \mu \mathrm{M}$ ) for PCR. The realtime PCR reactions were monitored using the 7900HT Fast RealTime PCR System (Applied Biosystems; Foster City, Calif., USA). The primer sequences are listed in table 1. Standard reference curves were obtained concomitantly with the unknown samples for the calculation of gene copy numbers in each real-time PCR 
Table 1. Oligonucleotide sequence for a selected list of genes for quantitative real time-PCR

\begin{tabular}{|c|c|c|c|}
\hline Gene name & Sense & Anti-sense & Size, bp \\
\hline eNOS & 5'-CCСTACAACGGCTCCССТC-3' & 5'-GCTGTCTGTGTTACTGGATTCCTT-3' & 129 \\
\hline GPX3 & 5'-GACGGGGAGGAGTACATCCCT-3' & 5'-TTCACGTCCCCTTTCTCAA-3' & 278 \\
\hline HMOX1 & 5'-CCGAATGAACACTCTGGAGATG-3' & 5'-TGAGTGTCAGGACCCATCGGAT-3' & 273 \\
\hline IGFBP2 & 5'-ATGAAGGAGCT GGCTGTGTT-3' & 5'-TGCTTGTCACAGTTGGGGATG-3' & 239 \\
\hline p53 & $5^{\prime}$-CCTCACCATCATCACACTGG-3' & 5'-GGCTTCTTCTTTTGCACTGG-3' & 216 \\
\hline SOD1 (CuZnSOD) & 5'-GGGATCGCCCAA TAAACATTC-3' & 5'-AGTAGACAATAGGACGATCGAC-3' & 70 \\
\hline SOD2 (MnSOD) & 5'-CATTGAAGTTCACGGTGGAG-3' & 5'-TAGAACAAGCGGCAATCTGCA-3' & 236 \\
\hline SOD3 (EcSOD) & 5'-GGC CCA GCT CCA GAC TGA-3' & $5^{\prime}$-CTC AGG TCC CCG AAC TCA TG-3' & 193 \\
\hline TGFB2 & 5' -TCGACATGGACCAGTTCATGCG-3' & 5'-CCCTGGTGCTGTTGTAGATGGA-3' & 147 \\
\hline TRAF5 & 5'-AAGATCATTCTGGGACGAT-3' & 5'-GTATTCAGGACACAAGTTTT-3' & 219 \\
\hline VEGF & 5'-GAGACCCTGGTGGACATC-3' & 5'-TTTCTTTGGTCTGCATTC-3' & 79 \\
\hline GAPDH & 5'-AATGACCCCTTCATTGACCTCC-3' & 5'-GCTTCCCATTCTCAGCCTTGAC-3' & 100 \\
\hline
\end{tabular}

experiment. Gene expression was quantified from the standard curve. Results were normalized to the copy numbers of GAPDH gene products.

\section{Functional and Molecular Assessment of Senescent}

Endothelial Cells

Basal and Stimulated Levels of Cyclic GMP $[1,2]$

After washing twice with warm HEPES-containing buffer, different inhibitors [indomethacin (cyclooxygenase inhibitor; 10 $\mu \mathrm{M})$, captopril (angiotensin-converting enzyme inhibitor; $10 \mu \mathrm{M}$ ) and isobutyl methylxanthine (non-selective phosphodiesterase inhibitor; $100 \mu \mathrm{M}$ )] were added and incubation allowed for $45 \mathrm{~min}$. Cells were then exposed to A23187 $\left(10^{-6} \mathrm{M}\right)$, bradykinin $\left(10^{-6} \mathrm{M}\right)$ or vehicle (distilled water). After stimulation, the buffer was replaced with absolute ethanol and sodium acetate. Cyclic GMP levels were measured by radioimmunoassay (Perkin Elmer, Wellesley, Mass., USA). Values are expressed as femtomole (fmol) per million cells and shown as means \pm SEM. The cellular density was defined using the hemacolor method.

Protein Presence by Western Blotting [1]

Cultured endothelial cells were collected in ice-cold lysis buffer containing a cocktail of protease inhibitors (1 mM phenylmethylsulfonyl fluoride, $100 \mathrm{ng} / \mathrm{ml}$ trypsin inhibitor, $20 \mu \mathrm{g} / \mathrm{ml}$ leupeptin and $1 \mu \mathrm{M}$ pepstatin). Thirty micrograms of total protein were separated on 10 or $12.5 \%$ polyacrylamide gel and transferred to polyvinylidene difluoride membranes. The blot was blocked and incubated with antibodies at $4^{\circ} \mathrm{C}$ overnight, followed by incubation with HRP-labeled secondary antibody (Amersham Biosciences, Freiburg, Germany) prior to image detection using an enhanced chemiluminescence kit (Amersham Biosciences). The protein presence for each blot was normalized to the housekeeping protein, $\beta$-actin, before the analysis was performed.

\section{SOD2 Activity [16]}

Endothelial cells were collected in cold buffer (20 mM HEPES, pH 7.2, containing $1 \mathrm{mM}$ EGTA, $210 \mathrm{mM}$ mannitol, $70 \mathrm{mM} \mathrm{su}$ crose). Two to $5 \mu \mathrm{g}$ of total protein were used in the presence of potassium cyanide (to inhibit $\mathrm{Cu}-\mathrm{Zn} \mathrm{SOD}$ ) to measure the SOD2 activity using a commercially available ELISA kit (Cayman, Ann Arbor, Mich., USA).

\section{Electrophoretic Mobility Shift Assay [17]}

Both stimulated and unstimulated endothelial cells were washed 3 times with ice-cold Tris buffer solution. Cells were then scraped in $1 \mathrm{ml}$ cold buffer and incubated for $15 \mathrm{~min}$ on ice. The cells were centrifuged at $15,000 \mathrm{rpm}$ at $4^{\circ} \mathrm{C}$ for $15 \mathrm{~min}$ to remove the supernatant. The cell pellet was resuspended in another cold buffer and mixed thoroughly. After addition of $0.5 \%$ Nonidet P40 , the mixture was incubated on ice for $30 \mathrm{~min}$ and centrifuged $(15,000 \mathrm{rpm})$ at $4^{\circ} \mathrm{C}$ for $15 \mathrm{~min}$. The supernatant $(50 \mu \mathrm{l})$ was collected as nuclear protein and quantified. Consensus oligonucleotides containing the sequence of the binding site for NFKB (1.75 $\mathrm{pmol} / \mu \mathrm{l})$ were radiolabeled with $[\gamma-32 \mathrm{P}]$ ATP (specific activity, $3,000 \mathrm{Ci} / \mathrm{mmol})$. Nuclear proteins $(5 \mu \mathrm{g})$ were incubated with $30,000 \mathrm{cpm}$ of labeled oligonucleotides in the reaction buffer for $20 \mathrm{~min}$ at room temperature and separated by $6 \%$ non-denaturing polyacrylamide gel electrophoresis. The vacuum dried gel was subjected to autoradiography and the image developed on Fuji RX film.

\section{Fluorescence Studies}

Oxidative stress (reactive oxygen species) in cultured cells were assessed using DCF $\left(2^{\prime}, 7^{\prime}\right.$-dichlorodihydrofluorescein diacetate) as modified from Yi et al. [12]. Briefly, the culture medium was replaced with HEPES-Tris buffer ( $\mathrm{pH}$ 7.4) containing DCF $(5 \mu \mathrm{M}), \mathrm{NaCl}(140 \mathrm{mmol} / \mathrm{l}), \mathrm{KCl}(5.4 \mathrm{mmol} / \mathrm{l}), \mathrm{CaCl}_{2}(2.4 \mathrm{mmol} / \mathrm{l})$, $\mathrm{MgSO}_{4}(0.7 \mathrm{mmol} / \mathrm{l}), \mathrm{Na}_{2} \mathrm{SO}_{4}(2.5 \mathrm{mM})$ and glucose $(10 \mathrm{~mm})$ for $30 \mathrm{~min}$ at $37^{\circ} \mathrm{C}$. The cells were washed with PBS before measuring the emitted fluorescence (excitation 492-495 nm; emission 517$527 \mathrm{~nm}$ ). The fluorescence readings were normalized to the number of micrograms of cellular protein collected.

\section{Data Analysis and Statistics}

For the cyclic GMP measurements, telomerase activity, RTPCR, Western blotting, SOD2 activity, electrophoretic mobility shift assay and oxidative stress experiments, statistical analysis of the data was performed using Student's t test for paired observa- 
tions. $\mathrm{p}$ values less than 0.05 were considered to indicate statistically significant differences. For the microarray studies, the raw data were normalized using 2 different strategies. First, a global Affymetrix scaling (scaling to all probe sets) and normalization for comparison analysis to detect and quantify changes in gene expression was performed using GeneChip Operating Software 1.4. A quantitative estimate of the gene expression changes was produced in the form of fold change (greater than 2-fold change). Student's t test for paired observation was used to calculate the difference between 2 groups (P1 and P4). Second, GeneSpring GX 9 (Agilent Technologies; Santa Clara, Calif., USA) was used for data processing. Statistically significant genes with fold change greater than 2 with reference to the control (young cells at P1) were shown and discussed. To evaluate the similarities between cultures derived from regenerated endothelium and senescent cells, multiple comparisons were made accordingly.

\section{Drugs and Materials}

Bradykinin, DCF $\left(2^{\prime}, 7^{\prime}\right.$-dichlorodihydrofluorescein diacetate), isobutyl methylxanthine, indomethacin and A23187 were obtained from Sigma (St. Louis, Mo., USA). Antibodies for TNF receptor-associated factor 5 (TRAF5) were purchased from Santa Cruz Biotechnology (Santa Cruz, Calif., USA). MnTMPyP [Mn(III)tetrakis(1-methyl-4-pyridyl)porphyrin tetratosylate hydroxide] and the antibodies against eNOS and captopril were obtained from Calbiochem (Behring, La Jolla, Calif., USA). The antibodies against SOD2 were purchased from BD Biosciences (Palo Alto, Calif., USA) and those against p53 from Cell Signaling (Beverly, Mass., USA).

\section{Results}

The growth rate of cultured endothelial cells was reduced progressively from P1 (PDL 3.83) to P4 (cumulative population doubling 11.34; fig. 1a, b). To evaluate the senescence status of these cells, telomerase activity was measured. The lysate of endothelial cells $\left(2 \times 10^{4}\right)$ at P1 possessed approximately $27 \%$ of the telomerase activity compared to the telomerase-positive cancer cell extract control (fig. 1c). The activity was significantly reduced in endothelial cells at P4, which contained only $10.8 \%$ of telomerase activity compared to cells at P1. Cytosolic SA$\beta$-Gal staining (measured at $\mathrm{pH}$ 6) showed higher levels in cells at $\mathrm{P} 4$ than in those at $\mathrm{P} 1$ (fig. 1d). A similar observation was made when the staining was performed at $\mathrm{pH}$ 4 to measure the lysosomal content of total $\beta$-galactosidase (data not shown). Treatment with $\mathrm{H}_{2} \mathrm{O}_{2}$ did not produce significant cell death but significantly enhanced the intensity of cytosolic SA- $\beta-$ Gal staining (measured at $\mathrm{pH}$ 6) compared to control. Simultaneous incubation with MnTMPyP reduced the color intensity in $\mathrm{H}_{2} \mathrm{O}_{2}$-treated cells (fig. 1e).

Both the mRNA and protein levels of eNOS were reduced significantly in cells at P4 (fig. 2a, b). In addition, the basal levels of cyclic GMP were reduced (by about 25\%) in those cells (fig. 2c) compared to cells at P1. Both bradykinin and A23187 augmented the levels of cyclic GMP. These responses were reduced significantly in cells at P4 (fig. 2d). Immunofluorescence staining demonstrated that von Willebrand factor and CD31, which are markers for endothelial cells, were present in cells at both passages (data not shown).

\section{Gene Expression Profiles in Senescent Endothelial Cells}

The gene expression profiles of endothelial cells at P1 and $\mathrm{P} 4$ were compared by microarray analysis. From the 6 sets of microarray data ( 3 each), the average presence of probe sets was comparable in cells at $\mathrm{P} 1$ and $\mathrm{P} 4$, and represented $62.20 \pm 0.30 \%$ and $62.63 \pm 0.40 \%$, respectively, of the 24,123 probe sets present in the porcine genome. Statistical analysis revealed that 528 identified genes were up-regulated significantly and 365 down-regulated in cells at P4 (see online suppl. table 1; all online materials are available at www.karger.com/doi/10.1159/000265563). The senescence marker, clusterin, was up-regulated in senescent cells. Genes regulating cell growth and apoptosis, including caspase 3 , insulin-like growth factor 2, IкB, IL6 and ubiquitin-specific protease were down-regulated while c-Jun protein, cyclin-dependent kinase-inhibitor 3 , P14ARF and TNF-receptor-associated factor 5 were upregulated significantly in senescent cells (fig. 3a). Genes possessing anti-inflammatory activities, such as alveolar macrophage-derived chemotactic factor-II, chemokine (C-X-C motif) ligand 2, IFN and its downstream signaling molecules (signal transducer and activator of transcription, IFN regulatory factor), colony-stimulating factor 2 (granulocyte-macrophage), lipopolysaccharide-induced TNF factor and RNA helicase (fig. 3b), and those involved in the anti-oxidation defense system, including glutathione peroxidase 3, superoxide dismutase ( $\mathrm{Mn}$ type), microsomal glutathione S-transferase 1 and thioredoxin interacting protein were down-regulated in senescent cells (fig. 3c), while superoxide dismutase ( $\mathrm{CuZn}$ type; SOD1) was not changed (data not shown). Genes involved in angiogenesis, coagulation, endothelial function and thrombosis, caveolin, thromboxane synthase 1, tissue factor and VEGF were down-regulated, while heat shock protein 90, somatostatin, cyclo-oxygenase 1 and TGF- $\beta$ were up-regulated (fig. $3 \mathrm{~d}$ ).

Most genes involved in cytoskeleton re-arrangement and morphogenesis were up-regulated in senescent cells, including connexin 43 , laminin, moesin, protein phosphatase 1, VE-cadherin (cadherin 5) and vinculin (fig. 3e). 

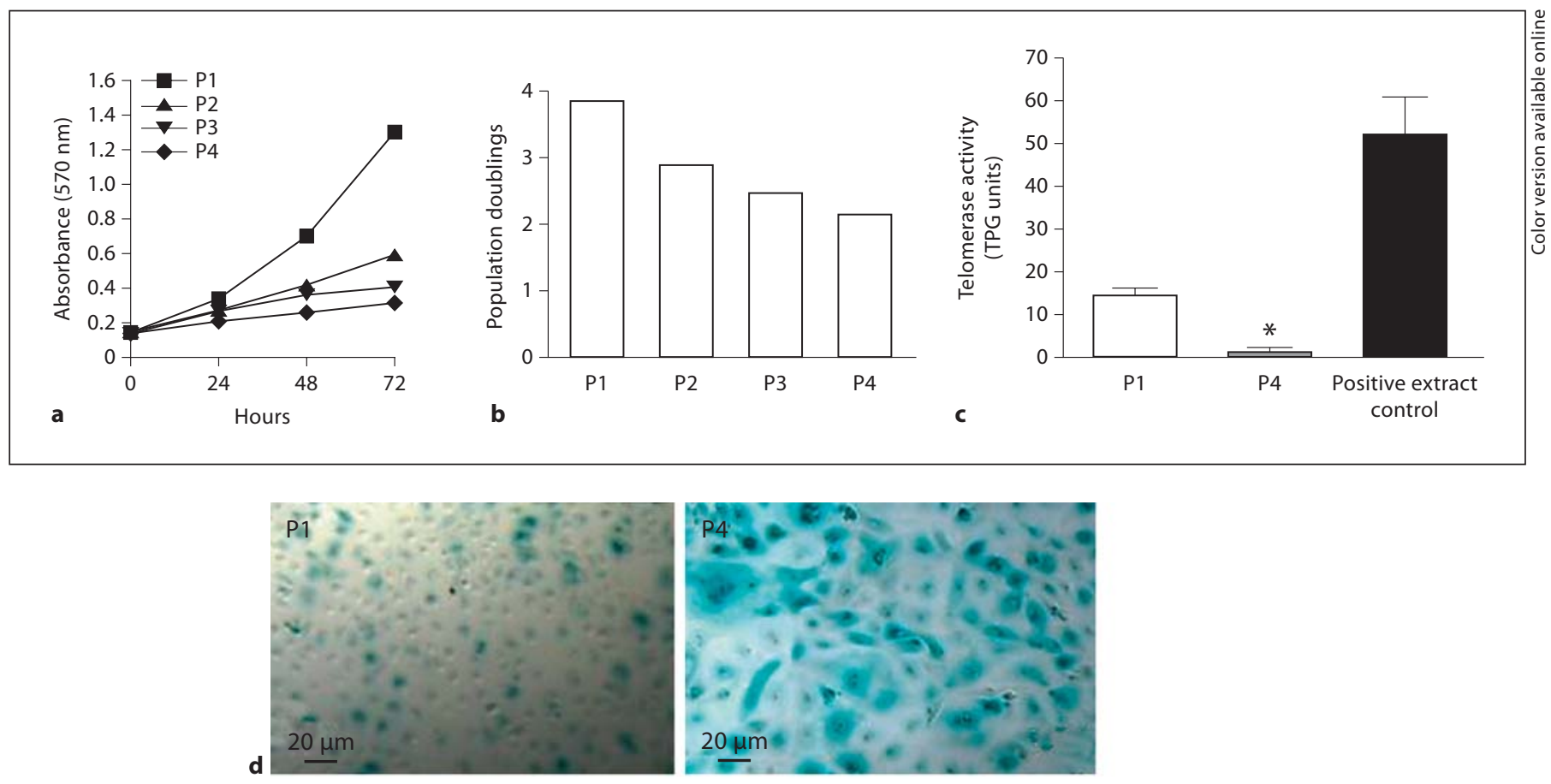

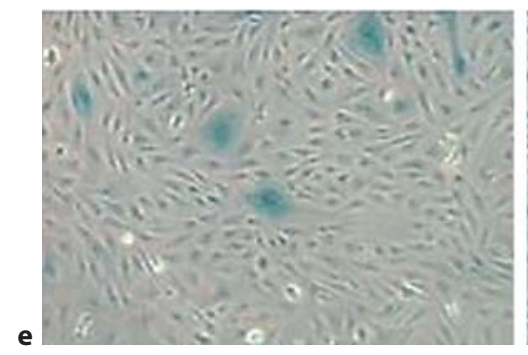

Control

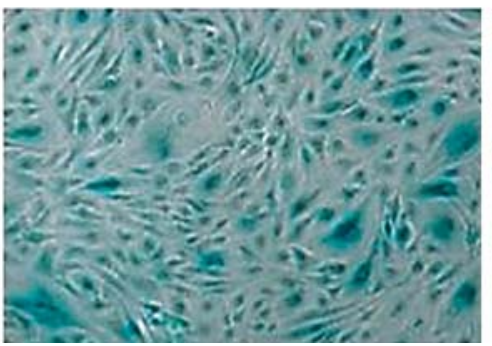

$\mathrm{H}_{2} \mathrm{O}_{2}$

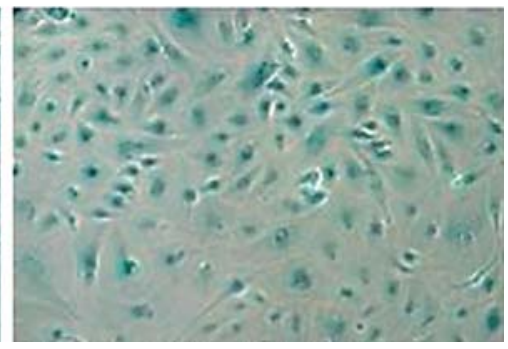

$\mathrm{H}_{2} \mathrm{O}_{2}+\mathrm{MnTMPyP}$
Fig. 1. Growth rate (a) and population doubling (b) of cultured coronary endothelial cells at passages $1-4$. Telomerase activity $(\mathrm{n}=4)$ was measured by a telomeric repeat amplification protocol assay kit. Data are shown as average total protein generated (TPG) units \pm SEM. ${ }^{*} \mathrm{p}<0.05$ vs. corresponding control at P1 (c). SA-
$\beta$-Gal staining at $\mathrm{pH} 6($ magnification $\times 100)$ was performed in cultured young (P1) and senescent (P4) cells (d), or in cells treated with or without $\mathrm{H}_{2} \mathrm{O}_{2}(100 \mu \mathrm{M})$ in the presence or absence of $\operatorname{MnTMPyP}\left(10^{-6} \mathrm{M}\right)(\mathbf{e})$.
Genes involved in lipid metabolism including 7-dehydrocholesterol reductase, acyl coenzyme A oxidase, fatty acid-binding protein 5, LDL receptor, scavenger receptor class B member 2 and TLR- 4 were up-regulated while peroxisome proliferator-activated receptor- $\gamma$ was downregulated in senescent cells (fig. 3f).

To further validate these changes, quantitative realtime PCR was performed for a number of selected genes, which showed consistent changes, including the downregulation of glutathione peroxidase 3 (GPX3), insulinlike growth factor binding protein 2 (IGFBP2), superoxide dismutase (Mn type; SOD2), thioredoxin reductase
(TXRND) and VEGF, and the up-regulation of p53, TGF$\beta$ and TRAF5 (fig. 4). Other genes including SOD1 and SOD3 were not changed (data not shown).

\section{Molecular Analysis of Cultured Senescent Endothelial Cells}

The electrophoretic mobility shift assay revealed that exposure to TNF- $\alpha$, at $1 \mathrm{ng} / \mathrm{ml}$ and $10 \mathrm{ng} / \mathrm{ml}$ for $2 \mathrm{~h}$, induced the significant translocation of NFкB into the DNA-binding site in the nucleus (fig. 5a). Senescent cells also demonstrated a significantly higher unstimulated level of $\mathrm{NF \kappa B}$ and a greater absolute $\mathrm{NF \kappa B}$ expression 


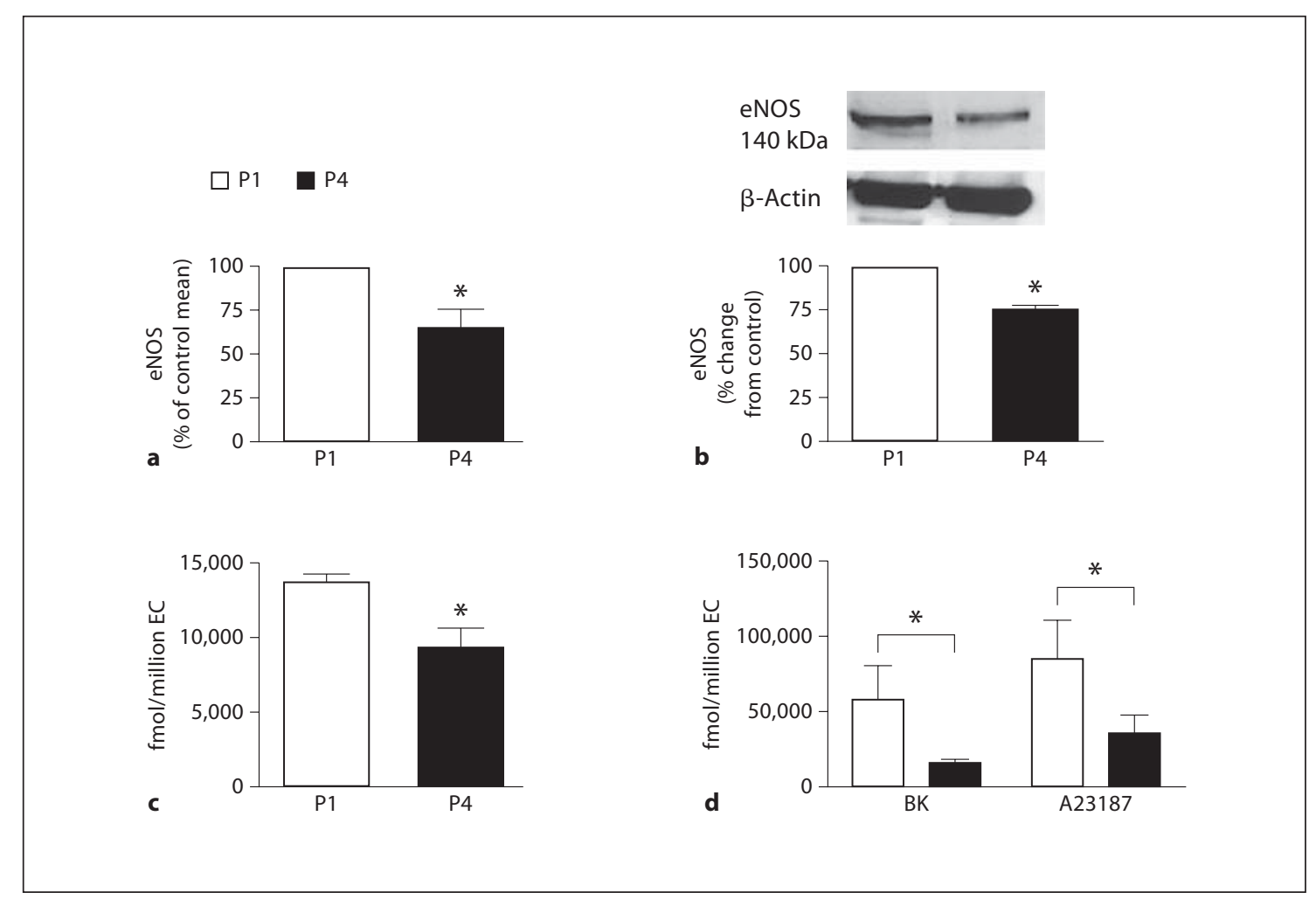

Fig. 2. a mRNA expression of eNOS by quantitative RT-PCR. b Protein presence of eNOS. The quantification of protein was normalized to that of the housekeeping protein, $\beta$-actin, for equal loading. c Cyclic GMP levels under basal conditions. d Cyclic GMP levels upon stimulation with bradykinin (BK; $\left.10^{-6} \mathrm{M}\right)$ and A23187 $\left(10^{-6} \mathrm{M}\right)(\mathrm{n}=6) .{ }^{*} \mathrm{p}<0.05$ vs. corresponding control.

Fig. 3. Differential expression of genes in senescent cells. Statistically significant genes $(\mathrm{p}<0.05 ; \mathrm{n}=3)$ were classified according to their biological functions. a Cell growth and apoptosis. b Antiinflammation. c Anti-oxidative properties. d Angiogenesis, coagulation, endothelial function and thrombosis. e Cytoskeleton and morphogenesis. f Lipid metabolism. Data were expressed as fold change of the control (P1). 7-DHC reductase $=7$-dehydrocholesterol reductase; ACOX1 = acyl-coenzyme A oxidase 1 palmitoyl; AMCF2 = alveolar macrophage-derived chemotactic factorII; CASP 3 = caspase 3 ; CDK inhibitor $3=$ cyclin-dependent kinase inhibitor 3; CLU = clusterin; CX43 = connexin 43; CSF2 = colony-stimulating factor 2 (granulocyte-macrophage); CXCL2 = chemokine ( $\mathrm{C}-\mathrm{X}-\mathrm{C}$ motif) ligand 2 ; F2 = coagulation factor II; FABP5 = fatty acid-binding protein 5; GPX3 = glutathione peroxidase 3; GUCY1B3 = guanylate cyclase 1 soluble $\beta 3$; HIF1 = hypoxia-inducible factor 1 , alpha subunit (basic helix-loop-helix transcription factor); HSP $90=90-\mathrm{kDa}$ heat shock protein; IF1 = IFN- $\alpha$-inducible protein; IFI $=$ IFN- $\alpha$-inducible protein (clone IFI-15K); IFNB1 = IFN- $\beta$; IFRD1 = IFN-related developmental regulator 1; IGF2 = insulin-like growth factor 2 (somatomedin A); IкB = nuclear factor of kappa light polypeptide gene enhancer in $\mathrm{B}$-cells inhibitor- $\alpha$; Integrin $\beta 5=$ integrin- $\beta 5$ isoform 3 ; IRF1 = IFN regulatory factor 1 ; IRF7 = IFN regulatory factor 7; LAMB1 = laminin- $\beta 1$; LDLR $=$ LDL receptor; LITAF = lipopolysaccharide-induced TNF factor; MGST1 = microsomal glutathione S-transferase 1; MSN = moesin; P14ARF = P14 alternate-reading-frame protein 1 isoform 4 ; PP1 = protein phosphatase 1 ; PPAR- $\gamma=$ peroxisome proliferator-activated receptor- $\gamma$; PTGS1/ COX1 = prostaglandin-endoperoxide synthase $1 /$ cyclooxygenase 1 ; SCARB2 = scavenger receptor class B member 2 ; SOD2 = superoxide dismutase 2 , mitochondrial; SST = somatostatin; STAT5a = signal transducer and activator of transcription 5a; TBXAS $1=$ thromboxane A synthase 1 (platelet, cytochrome P450, family 5, subfamily A); TF = tissue factor; TLR4 = toll-like receptor 4; TRAF 5 = TNF receptor-associated factor 5; TXNIP = thioredoxin-interacting protein; UBP = ubiquitin-specific protease; $\mathrm{VCL}=$ vinculin; VE-cadherin = vascular endothelial-cadherin (cadherin 5); VWF = von Willebrand factor. 

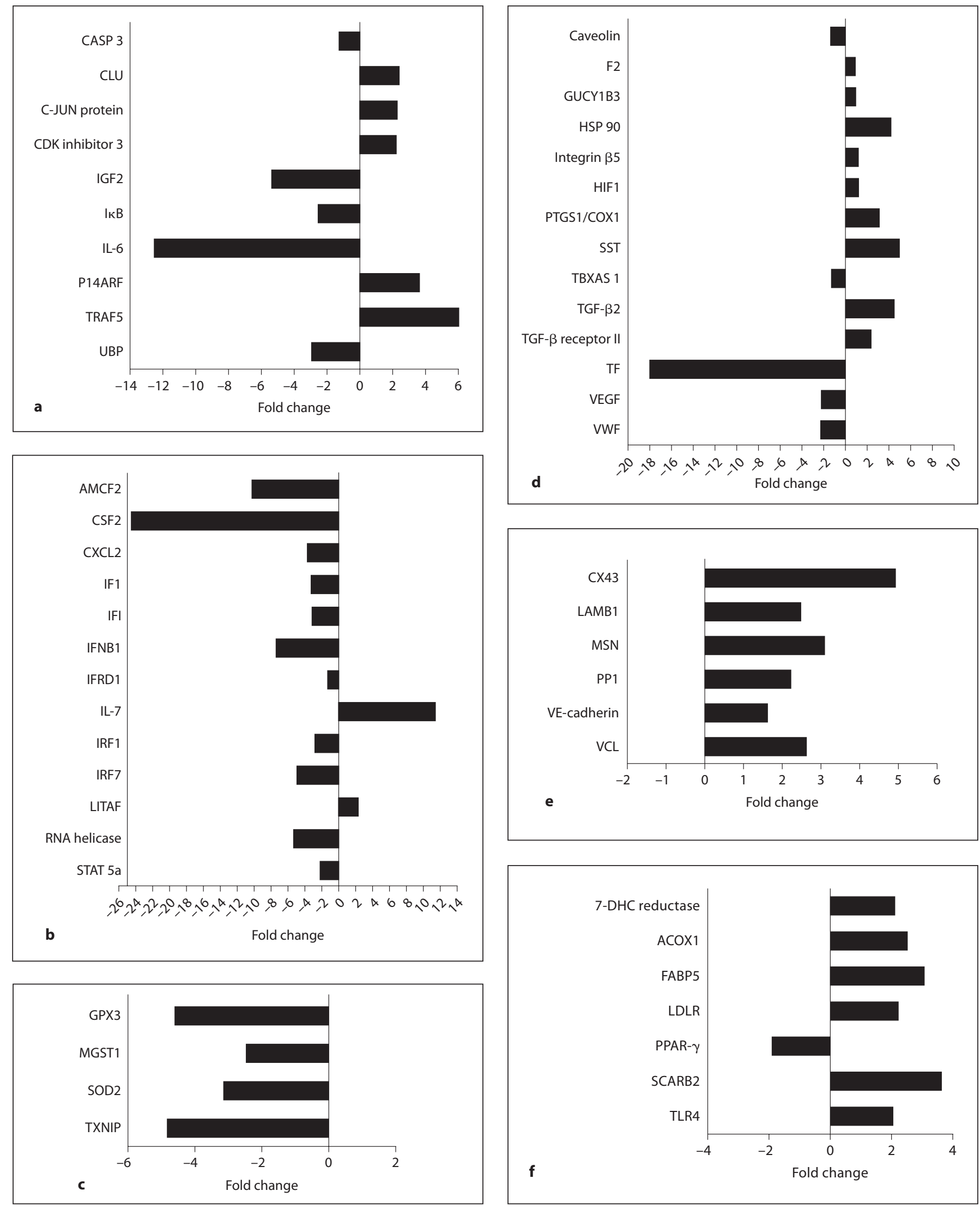


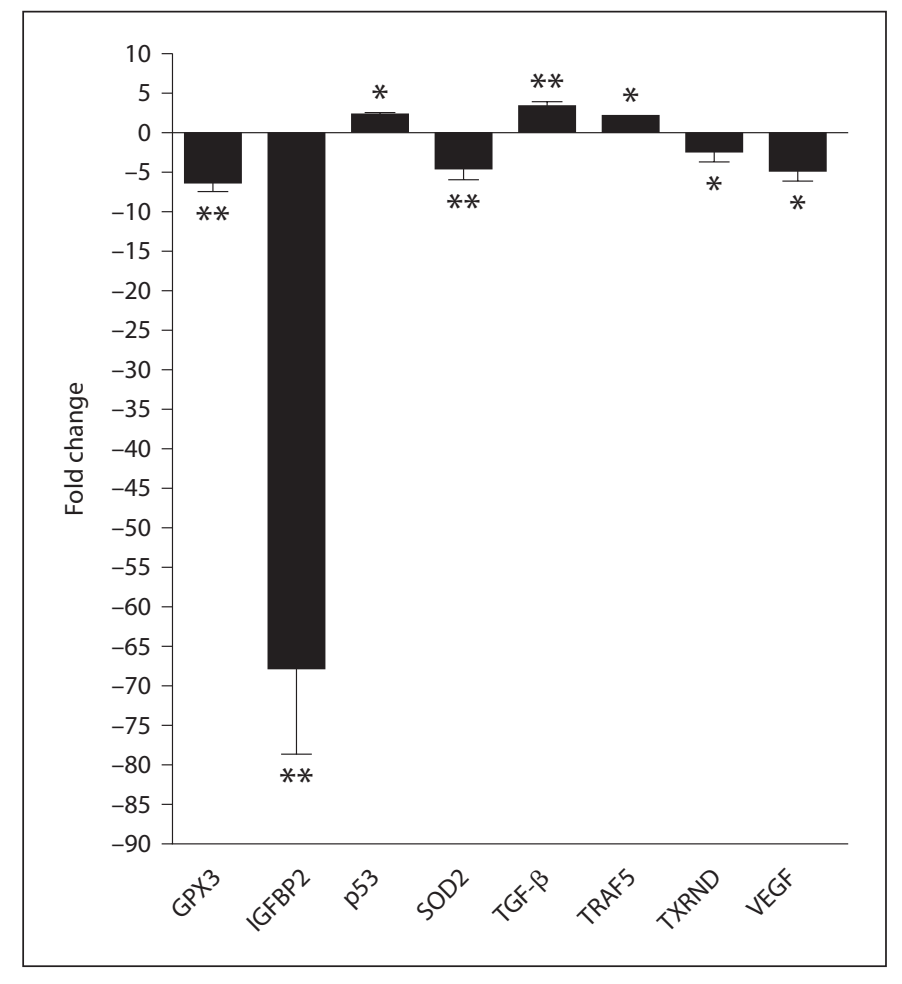

Fig. 4. mRNA expression of genes in cultured senescent endothelial cells at passage 4 by quantitative RT-PCR. Results were expressed as average fold-change \pm SEM compared to the controls at passage $1 .{ }^{*} \mathrm{p}<0.05,{ }^{* *} \mathrm{p}<0.01$ vs. corresponding control at passage $1(\mathrm{n}=2-4)$.

after treatment with $10 \mathrm{ng} / \mathrm{ml}$ TNF- $\alpha$ (fig. 5b). The percentage response to TNF- $\alpha$ in young and senescent cells was $232 \pm 86.5 \%$ and $201 \pm 43 \%$ of the basal level, respectively.

Western blotting demonstrated that SOD2, p53 and TRAF5 proteins were reduced (fig. $6 \mathrm{a}-\mathrm{c}$ ), in senescent cells. Similarly, the SOD2 activity was reduced (fig. 6d) significantly. Increased oxidative stress was observed after treatment with $\mathrm{H}_{2} \mathrm{O}_{2}$ and this increase was reversed by the simultaneous incubation with MnTMPyP (fig. 6e).

A simulation was performed for the protein-protein interactions predicted from the differences in gene expression in senescent cells as revealed by the microarray analysis. From the simulation results (pathway analysis; online suppl. fig. 1), the p53 pathway was shown to be activated by reduced expression of SOD2. Also, the activation of NFKB was induced by augmented mRNA expression of TRAF1, 5 as well as a reduced level of IкB. Both activated pathways lead to cellular apoptosis and aging.

\section{Discussion}

The proliferative capacity of endothelial cells is tightly regulated both in vivo and in vitro [15]. The present study demonstrates that cultured coronary arterial endothelial cells undergo replicative senescence in vitro upon multiple passaging, leading to endothelial dysfunction. Primary cultures of coronary endothelial cells [1] at P1 ('young cells') exhibit a typical cobblestone appearance and the cells at P4 showed a senescent-like 'fried egg' appearance. The homogeneity of the endothelial population was monitored by immunofluorescence staining, which demonstrated more than $99 \%$ positive cells for von Willebrand factor and CD31, and negative for $\alpha$ actin smooth muscle in cells at both P1 and P4 (data not shown), suggesting the homogenous origin of endothelial cells in the primary cultures [1]. Upon multiple passaging until P4 ('senescent cells'), the cultures show an enlarged, flattened and senescent morphology (online suppl. fig. 2), reduced proliferative capacity since P2 and onwards, decreased telomerase activity and increased expression of SA- $\beta$-Gal activity. Cultured endothelial cells after $\mathrm{P} 4$ could not reach confluence after 1 week under standard culture conditions. Similar findings have also been reported by other groups under in vivo and in vitro conditions $[1,2,7,18]$. Since hydrogen peroxide is a prooxidant that leads to premature senescence, it is widely used for the study of the underlying mechanisms involved. In the present study, SA- $\beta$-Gal activity was increased in $\mathrm{H}_{2} \mathrm{O}_{2}$-treated cells, suggestive of the occurrence of senescence in the cultured endothelial cells. The observation that MnTMPyP reduces the increased activity of the enzyme indicates the key role of oxygen-derived free radicals in the senescence process induced by $\mathrm{H}_{2} \mathrm{O}_{2}$.

Senescent endothelial cells by multiple passaging exhibit decreased mRNA (measured by real-time PCR) and protein levels [18] of eNOS, resembling the observations made in regenerated cells in vivo [1]. Caveolin, a structural protein of caveolae in endothelial cells, is essential in NO-mediated relaxations [19] and endothelium-dependent hyperpolarizations [20]. A reduced caveolin expression was observed in the present study which may also account for the endothelial dysfunction in senescent cells. However, it is still debatable whether or not NO is involved in endothelial senescence. Neither a NO donor nor a NOS inhibitor modulate the telomerase activity or the proliferations of human umbilical vein endothelial cells [21], suggesting that NO may not contribute directly to the phenomenon. However, other studies have reported that supplementation with $\mathrm{NO}$ activates telomerase 
Fig. 5. a Representative NFкB activation by TNF- $\alpha(10 \mathrm{pg} / \mathrm{ml}$ to $10 \mathrm{ng} / \mathrm{ml}$ for $2 \mathrm{~h})$ in young cells (P1). b Stimulated level of NFкB by TNF- $\alpha$ (10 ng/ml for $2 \mathrm{~h})$ in P1 and $\mathrm{P} 4$ cells. ${ }^{*} \mathrm{p}<0.05$ vs. corresponding control $(n=4)$.
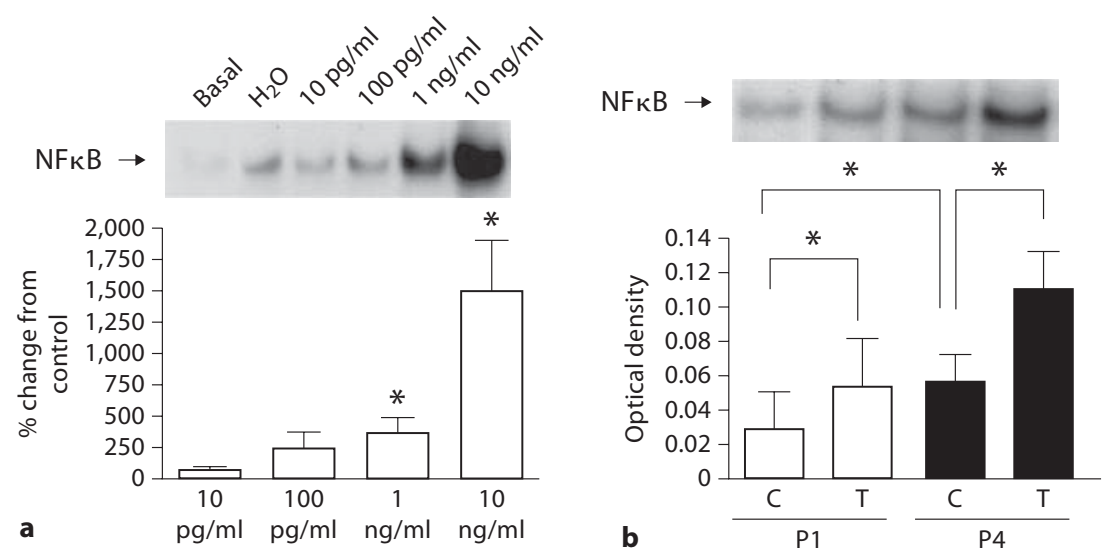

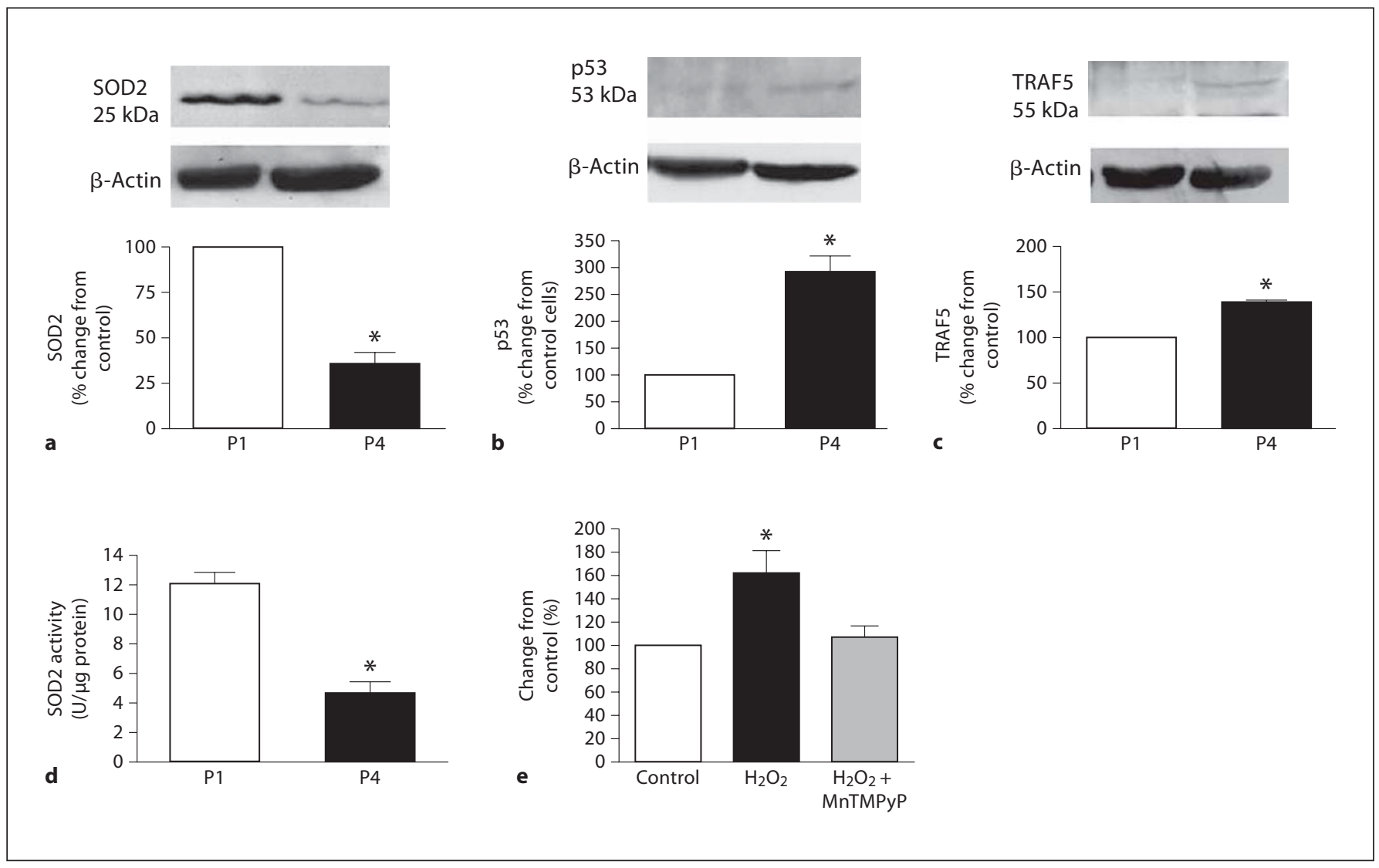

Fig. 6. a-c The protein presence of SOD2, p53 and TRAF5 in young cells (P1) and senescent cells (P4) $(n=3-6) .{ }^{*} \mathrm{p}<0.05$ vs. corresponding control. The quantification of proteins was normalized to that of the housekeeping protein, $\beta$-actin, for equal loading. d Activity of SOD2/MnSOD in P1 and P4 cells $(n=3-5)$. e Level of oxidative stress in cells with or without treatments [control, $\mathrm{H}_{2} \mathrm{O}_{2}$ and in the presence of MnTMPyP $\left(10^{-6} \mathrm{M}\right)$ ] as measured by DCF $\left(2^{\prime}, 7^{\prime}\right.$-dichlorodihydrofluorescein diacetate) fluorescence. ${ }^{*} \mathrm{p}<0.05$ vs. corresponding control cells. 
activity and hence delays the onset of endothelial senescence [9], suggesting an atheroprotective role of NO. The present data contrast with the absence of a difference in cyclic GMP in response to bradykinin and A23187 in primary cultures derived from regenerated cells [1]. The observed difference is probably due to the stage at which regenerated cells are obtained. Thus, coronary arteries with regenerated cells harvested 4 months after angioplasty have a reduced response to bradykinin while the Gi-protein-dependent serotonin-induced relaxation is already diminished 4 weeks after the injury [22].

The present study indicates that the senescence in vivo [23-26] and in vitro (present study) is related to activated $\mathrm{NF \kappa B}$ and p53 signaling pathways. This conclusion is supported by the following findings.

(1) Reduced expression of growth factors such as VEGF and IGF2 [27,28], causing reduced proliferative capacity in senescent cells.

(2) Elevated oxidative stress in senescent cells due to the reduced capability of anti-oxidation enzymes (mainly SOD2 but not SOD1 and 3 as revealed from the present microarray and real-time PCR studies) [14]. This causative role of oxidative stress was further confirmed in cells treated with $\mathrm{H}_{2} \mathrm{O}_{2}$ plus MnTMPyP. The reduced telomerase activity from the nucleus to the cytosol by oxidative stress may contribute to the inability to maintain telomere length, a critical step for functional activity and longevity of endothelial cells [14].

(3) Activated NFKB-dependent apoptosis (probably associated with increased oxidative stress [26]). The elevated TRAF5 protein and genomic changes on NFкB pathway (including the increased TRAF5 and reduced I $\mathrm{B}$ expression) suggest facilitated activation of NFKB signaling mechanisms $[29,30]$. The accelerated translocation of NFKB into the nucleus, as revealed by the electrophoretic mobility shift assay, must mediate the transcription of inflammatory components in senescent cells to promote endothelial aging $[26,31]$. This then confirms the link between activated NFкB, senescence and the pathophysiological consequences of endothelial dysfunction.

(4) Elevated oxidative stress in senescent cells activates p53 protein and hence its signaling mechanism both in vivo [32] and in vitro (present data). This includes the genomic changes of the p53 pathway (including increased clusterin [33] and P14ARF [34] expression) and the increased stabilities of $\mathrm{p} 53$, as indicated by the decreased ubiquitin-protease system (the breakdown of p53 is reduced by reduced expression of ubiquitinspecific protease in senescent cells), contributing to apoptosis $[34,35]$ and promoting cellular senescence in endothelial cells. The cultured endothelial cells at $\mathrm{P} 4$ also exhibit functional senescence. This conclusion is based on the finding that an immunoprotective role is observed after the cytotoxic stimulation by TNF- $\alpha$ at $\mathrm{P} 1$ but not at $\mathrm{P} 4$. This conclusion is strengthened by the earlier demonstration that the protein presence of the immunomodulatory protein surfactant protein $\mathrm{D}$ is diminished at $\mathrm{P} 4$ compared to $\mathrm{P} 1$ [36]. At P1, stimulation with the inflammatory cytokine tumor necrosis factor- $\alpha$ increased the expression of surfactant protein $\mathrm{D}$ at both the genomic and proteomic levels, but this response was not observed at $\mathrm{P} 4$, suggesting a protective role of surfactant protein $\mathrm{D}$ in young endothelial cells [36].

Earlier work on the genetic changes occurring in senescent endothelial cells of the human umbilical vein suggested a reduced pro-inflammatory and immune response under quiescent conditions (reduced serum level), while pro-inflammatory components like ICAM-1 and growth arrest and DNA-damage-inducible protein were induced under stimulation (high serum level) after prolonged passaging [10]. These earlier observations are in line with the findings in the present study as the gene expression of anti-inflammatory components including IFN-inducible factors and IL- 6 in senescent cells is reduced in the senescent cells. Predicting the gene expression pattern in response to stress in different cell types is complicated by the different metabolic demands, irrespective of the common initiator (e.g. replicative senescence) [10].

Since senescence of vascular endothelial cells accelerates the progression of atherosclerosis $[4,5]$, the comparison of the microarray data from 2 different pathophysiological conditions in vivo (regenerated endothelial cells) [1] and in vitro (senescent endothelial cells; present study) permits the study of the similarities and differences between the two. This may represent a relevant model for the study of the pathophysiology in vascular diseases in vivo if multiple passaging induces changes identical to those observed in regenerated cells. Essentially, both senescent and regenerated cells demonstrated a reduced expression of anti-oxidative [37] and anti-inflammatory [38] genes (see the analyzed microarray data for regenerated cells [1] and senescent cells with reference to young cells at P1; online suppl. table 2). In senescent cells, the up-regulated LPC-induced TNF factor expression should amplify any inflammatory process in response to chronic oxidative stress. However, it is still uncertain whether the increased oxidative stress is due to a reduced presence 
of anti-oxidative enzymes (e.g. SOD2 and GPX3) after multiple passaging per se or results from the relatively high oxygen concentration under cell culture conditions [39].

The senescent cells of the present study differ from the primary cultures of regenerated endothelium as regards the genomic changes related to angiogenesis, coagulation and endothelial function (online suppl. table 2). An increased expression of coagulation factor II and thromboxane synthase and a decreased expression of cyclooxygenase 1 were only observed in regenerated cells [1]. Genes related to the cytoskeleton and morphogenesis also were expressed differently in the 2 cell types. More importantly, the expression of matrilysin-related protein, observed in regenerated but not in native cells [1], was not detected in senescent cells. Likewise, the differential expression of adipocyte fatty acid-binding protein (AFABP) and peroxisome proliferators-activated receptor$\gamma$ (online suppl. table 2) observed in cultures of regenerated but not in senescent cells may be involved in the altered lipid metabolism and macrophage activation characteristic of atherosclerosis [40]. Indeed, disruption of gene encoding for A-FABP has a beneficial effect on dyslipidemia [41] and atherosclerosis [42]. Pharmacological inhibition of A-FABP also reduces the atherosclerotic lesion area in animals [43]. Changes observed in senescent but not in regenerated cells include reduced expression of acyl-coenzyme A oxidase 1 and increased FABP5 and 7-dehydrocholesterol reductase protein which are in- volved in $\beta$-oxidation, cholesterol transport and synthesis [44]. This is associated in senescent cells with elevated level of expression of the LDL receptor, suggesting an increased uptake of extracellular lipids possibly due to the augmented expression of the angiotensin II receptor [45]. The present observations thus predict that in senescent endothelial cells the increased level of scavenger receptor class B member 2 will result in a negative feedback mechanism on lipid efflux [46].

In summary, the present study demonstrates that in vitro passaging of cultured coronary endothelial cells until P4 leads to endothelial senescence and is associated with endothelial dysfunction, increased oxidative stress and activation of the $\mathrm{p} 53$ and NFKB pathways. Despite genomic similarities between the senescent endothelial cells of the present study and these derived from regenerated endothelium in earlier work, the former do not represent an accurate in vitro model of endothelial regeneration.

\section{Acknowledgments}

We thank Dr. M.P. Fournet-Bourguignon (Institut de Recherches, Servier, Suresnes, France) for her advice in setting up the primary culture model. This work was supported in part by grant HKU7490/06M of the Research Grant Council of Hong Kong and the Research Centre of Heart, Brain, Hormone \& Healthy Aging of the University of Hong Kong.

\section{References}

1 Lee MYK, Tse HF, Siu CW, Zhu SG, Man RYK, Vanhoutte PM: Genomic changes in regenerated porcine coronary arterial endothelial cells. Arterioscler Thromb Vasc Biol 2007;27:2443-2449.

-2 Fournet-Bourguignon MP, Castedo-Delrieu M, Bidouard JP, Leonce S, Saboureau D, Delescluse I, Vilaine JP, Vanhoutte PM: Phenotypic and functional changes in regenerated porcine coronary endothelial cells: increased uptake of modified LDL and reduced production of NO. Circ Res 2000;86:854-861.

3 Vanhoutte PM, Fournet-Bourguignon MP, Vilaine JP: Dysfonction de la voie du monoxide d'azote au cours de la régénération de l'endothélium coronarien. Académie Nationale de Médecine 2002;186:1525-1541.

-4 Brandes RP, Fleming I, Busse R: Endothelial aging. Cardiovasc Res 2005;66:286-294.

5 Erusalimsky JD, Kurz DJ: Cellular senescence in vivo: Its relevance in ageing and cardiovascular disease. Exp Gerontol 2005;40: 634-642.

Replicative Endothelial Senescence
6 Kudo FA, Warycha B, Juran PJ, Asada H, Teso D, Aziz F, Frattini J, Sumpio BE, Nishibe T, Cha C, Dardik A: Differential responsiveness of early- and late-passage endothelial cells to shear stress. Am J Surg. 2005;190: 763-769.

7 Minamino T, Komuro I: Vascular cell senescence: contribution to atherosclerosis. Circ Res 2007;100:15-26.

-8 Shi Q, Hubbard GB, Kushwaha RS, Rainwater D, Thomas CA, Leland MM, Vandeberg JL, Wang XL: Endothelial senescence after high-cholesterol, high-fat diet challenge in baboons. Am J Physiol Heart Circ Physiol 2007;292:H2913-H2920.

-9 Hayashi T, Matsui-Hirai H, Miyazaki-Akita A, Fukatsu A, Funami J, Ding QF, Kamalanathan S, Hattori Y, Ignarro LJ, Iguchi A: Endothelial cellular senescence is inhibited by nitric oxide: implications in atherosclerosis associated with menopause and diabetes. Proc Natl Acad Sci USA 2006;103:1701817023.
10 Shelton DN, Chang E, Whittier PS, Choi D, Funk WD: Microarray analysis of replicative senescence. Curr Biol 1999:9:939-945.

- 11 Ota H, Eto M, Kano MR, Ogawa S, Iijima K, Akishita M, Ouchi Y: Cilostazol inhibits oxidative stress-induced premature senescence via upregulation of Sirt1 in human endothelial cells. Arterioscler Thromb Vasc Biol 2008;28:1634-1639.

12 Shi Y, So KF, Man RY, Vanhoutte PM: Oxygen-derived free radicals mediate endothelium-dependent contractions in femoral arteries of rats with streptozotocin-induced diabetes. Br J Pharmacol 2007;152:1033-1041.

13 Kueng W, Silber E, Eppenberger U: Quantification of cells cultured on 96-well plates. Anal Biochem 1989;182:16-19.

14 Haendeler J, Hoffmann J, Diehl JF, Vasa M, Spyridopoulos I, Zeiher AM, Dimmeler S: Antioxidants inhibit nuclear export of telomerase reverse transcriptase and delay replicative senescence of endothelial cells. Circ Res 2004;94:768-775. 
15 Kurz DJ, Hong Y, Trivier E, Huang HL, Decary S, Zang GH, Lüscher TF, Erusalimsky JD: Fibroblast growth factor-2, but not vascular endothelial growth factor, upregulates telomerase activity in human endothelial cells. Arterioscler Thromb Vasc Biol 2003; 23:748-754.

16 MacMillan-Crow LA, Crow JP, Kerby JD, Beckman JS, Thompson JA: Nitration and inactivation of manganese superoxide dismutase in chronic rejection of human renal allografts. Proc Natl Acad Sci USA 1996;93: 11853-11858

17 Marumo T, Schini-Kerth VB, Busse R: Vascular endothelial growth factor activates nuclear factor-kappaB and induces monocyte chemoattractant protein-1 in bovine retinal endothelial cells. Diabetes 1999;48:11311137.

-18 Shi Q, Aida K, Vandeberg JL, Wang XL: Passage-dependent changes in baboon endothelial cells: relevance to in vitro aging. DNA Cell Biol 2004;23:502-509.

19 Maniatis NA, Brovkovych V, Allen SE, John TA, Shajahan AN, Tiruppathi C, Vogel SM, Skidgel RA, Malik AB, Minshall RD: Novel mechanism of endothelial nitric oxide synthase activation mediated by caveolae internalization in endothelial cells. Circ Res 2006; 99:870-877.

-20 Saliez J, Bouzin C, Rath G, Ghisdal P, Desjardins F, Rezzani R, Rodella LF, Vriens J, Nilius B, Feron O, Balligand JL, Dessy C: Role of caveolar compartmentation in endothelium-derived hyperpolarizing factor-mediated relaxation: $\mathrm{Ca}^{2+}$ signals and gap junction function are regulated by caveolin in endothelial cells. Circulation 2008; 117:10651074.

21 Hong Y, Quintero M, Frakich NM, Trivier E, Erusalimsky JD: Evidence against the involvement of nitric oxide in the modulation of telomerase activity or replicative capacity of human endothelial cells. Exp Gerontol 2007;42:904-910.

-22 Shimokawa H, Flavahan NA, Vanhoutte PM: Natural course of the impairment of endothelium-dependent relaxations after balloon endothelium removal in porcine coronary arteries: possible dysfunction of a pertussis toxin-sensitive G protein. Circ Res 1989;65: 740-753.

23 Gorgoulis VG, Pratsinis H, Zacharatos P, Demoliou C, Sigala F, Asimacopoulos PJ, Papavassiliou AG, Kletsas D: p53-dependent ICAM-1 overexpression in senescent human cells identified in atherosclerotic lesions. Lab Invest 2005;85:502-511.

-24 Moiseeva O, Mallette FA, Mukhopadhyay UK, Moores A, Ferbeyre G: DNA damage signaling and p53-dependent senescence after prolonged beta-interferon stimulation. Mol Biol Cell 2006;17:1583-1592.
25 Romzova M, Hohenadel D, Kolostova K, Pinterova D, Fojtikova M, Ruzickova S, Dostal C, Bosak V, Rychlik I, Cerna M: NFkap$\mathrm{paB}$ and its inhibitor IkappaB in relation to type 2 diabetes and its microvascular and atherosclerotic complications. Hum Immunol 2006;67:706-713.

26 Donato AJ, Eskurza I, Silver AE, Levy AS, Pierce GL, Gates PE, Seals DR: Direct evidence of endothelial oxidative stress with aging in humans: relation to impaired endothelium-dependent dilation and upregulation of nuclear factor-kappaB. Circ Res 2007;100:1659-1666.

27 Delafontaine P, Song YH, Li Y: Expression, regulation, and function of IGF-1, IGF-1R, and IGF-1 binding proteins in blood vessels. Arterioscler Thromb Vasc Biol 2004;24: 435-444.

28 Thum T, Hoeber S, Froese S, Klink I, Stichtenoth DO, Galuppo P, Jakob M, Tsikas D, Anker SD, Poole-Wilson PA, Borlak J, Ertl G, Bauersachs J: Age-dependent impairment of endothelial progenitor cells is corrected by growth-hormone-mediated increase of insulin-like growth-factor-1. Circ Res 2007; 100:434-443.

29 Sakurai H, Suzuki S, Kawasaki N, Nakano H, Okazaki T, Chino A, Doi T, Saiki I: Tumor Necrosis Factor-alpha-induced IKK phosphorylation of NF-kappaB p 65 on serine 536 is mediated through the TRAF2, TRAF5, and TAK1 signaling pathway. J Biol Chem 2003;278:36916-36923.

30 Zirlik A, Bavendiek U, Libby P, MacFarlane L, Gerdes N, Jagielska J, Ernst S, Aikawa M, Nakano H, Tsitsikov E, Schönbeck U: TRAF$1,-2,-3,-5$, and -6 are induced in atherosclerotic plaques and differentially mediate proinflammatory functions of CD40L in endothelial cells. Arterioscler Thromb Vasc Biol 2007;27:1101-1107.

31 Helenius M, Kyrylenko S, Vehviläinen P, Salminen A: Characterization of aging-associated up-regulation of constitutive nuclear factor-kappa B binding activity. Antioxid Redox Signal 2001;3:147-156.

32 Han ES, Muller FL, Perez VI, Qi W, Liang HY, Xi L, Fu C, Doyle E, Hickey M, Cornell J, Epstein CJ, Roberts LJ, Van Remmen H, Richardson A: The in vivo gene expression signature of oxidative stress. Physiol Genomics 2008;34:112-126.

33 Trougakos IP, Gonos ES: Regulation of clusterin/apolipoprotein J, a functional homologue to the small heat shock proteins, by oxidative stress in ageing and age-related diseases. Free Radic Res 2006;40:1324-1334.

34 Campisi J, d’Adda di Fagagna F: Cellular senescence: when bad things happen to good cells. Nat Rev Mol Cell Biol 2007;8:729-740.

35 Marfella R, Di Filippo C, Laieta MT, Vestini R, Barbieri M, Sangiulo P, Crescenzi B, Ferraraccio F, Rossi F, D’Amico M, Paolisso G: Effects of ubiquitin-proteasome system deregulation on the vascular senescence and atherosclerosis process in elderly patients. J A Biol Sci Med Sci 2008;63:200-203.
36 Lee MYK, Sørensen GL, Holmskov U, Vanhoutte PM: The presence and activity of SP$\mathrm{D}$ in porcine coronary endothelial cells depend on Akt/PI3K, Erk and nitric oxide and decrease after multiple passaging. Mol Immunol 2009;46:1050-1057.

-37 Ohashi M, Runge MS, Faraci FM, Heistad DD: MnSOD deficiency increases endothelial dysfunction in ApoE-deficient mice. Arterioscler Thromb Vasc Biol 2006;26:23312336.

38 Zhang LN, Velichko S, Vincelette J, Fitch RM, Vergona R, Sullivan ME, Croze E, Wang YX: Interferon-beta attenuates angiotensin II-accelerated atherosclerosis and vascular remodeling in apolipoprotein $\mathrm{E}$ deficient mice. Atherosclerosis 2008;197:204-211.

-39 Busuttil RA, Rubio M, Dolle ME, Campisi J, Vijg J: Oxygen accelerates the accumulation of mutations during the senescence and immortalization of murine cells in culture. Aging Cell 2003;2:287-605.

40 Fu Y, Luo N, Lopes-Virella MF, Garvey WT: The adipocyte lipid binding protein (ALBP/ aP2) gene facilitates foam cell formation in human THP-1 macrophages. Atherosclerosis 2002;165:259-269.

41 Uysal KT, Scheja L, Wiesbrock SM, BonnerWeir S, Hotamisligil GS: Improved glucose and lipid metabolism in genetically obese mice lacking aP2. Endocrinology 2000;141: 3388-3396.

42 Boord JB, Maeda K, Makowski L, Babaev VR, Fazio S, Linton MF, Hotamisligil GS: Adipocyte fatty acid-binding protein, aP2, alters late atherosclerotic lesion formation in severe hypercholesterolemia. Arterioscler Thromb Vasc Biol 2002;22:1686-1691.

43 Furuhashi M, Tuncman G, Gorgun CZ, Makowski L, Atsumi G, Vaillancourt E, Kono K, Babaev VR, Fazio S, Linton M, Sulsky R, Robl JA, Parker RA, Hotamisligil GS: Treatment of diabetes and atherosclerosis by inhibiting fatty-acid-binding protein aP2. Nature 2007; 447:959-965.

-44 Exil VJ, Roberts RL, Sims H, McLaughlin JE, Malkin RA, Gardner CD, Ni G, Rottman JN, Strauss AW: Very-long-chain acyl-coenzyme a dehydrogenase deficiency in mice. Circ Res 2003;93:448-455.

45 Catar RA, Müller G, Heidler J, Schmitz G, Bornstein SR, Morawietz H: Low-density lipoproteins induce the renin-angiotensin system and their receptors in human endothelial cells. Horm Metab Res 2007;39:801805.

46 Webb NR, Connell PM, Graf GA, Smart EJ, de Villiers WJ, de Beer FC, van der Westhuyzen DR: SR-BII, an isoform of the scavenger receptor BI containing an alternate cytoplasmic tail, mediates lipid transfer between high density lipoprotein and cells. J Biol Chem 1998;273:15241-15248. 